\title{
Aspergilloma in a patient with a history of TB
}

\section{Henna Singh}

Department of General Medicine, University Hospital, Ayr, UK

\section{Correspondence to}

Dr Henna Singh,

singh-ing4u@hotmail.co.uk

Accepted 3 February 2014

CrossMark

To cite: Singh H. BMJ Case Rep Published online:

[please include Day Month

Year] doi:10.1136/bcr-2013-

203276

\section{DESCRIPTION}

An initial CT scan of the chest of a 73-year-old man showed an incidental 22-mm-wide cavitating lesion with a central small mass in the left upper lobe of his lung. He had a history of persistent cough with minimal expectoration for many years and was breathless on exertion. He never had haemoptysis. He had a history of tuberculosis (TB) from his childhood and had asthma. He had minimal change nephropathy diagnosed in 2000, of which he had several relapses over the past 9 years, responding to steroids. On examination, he

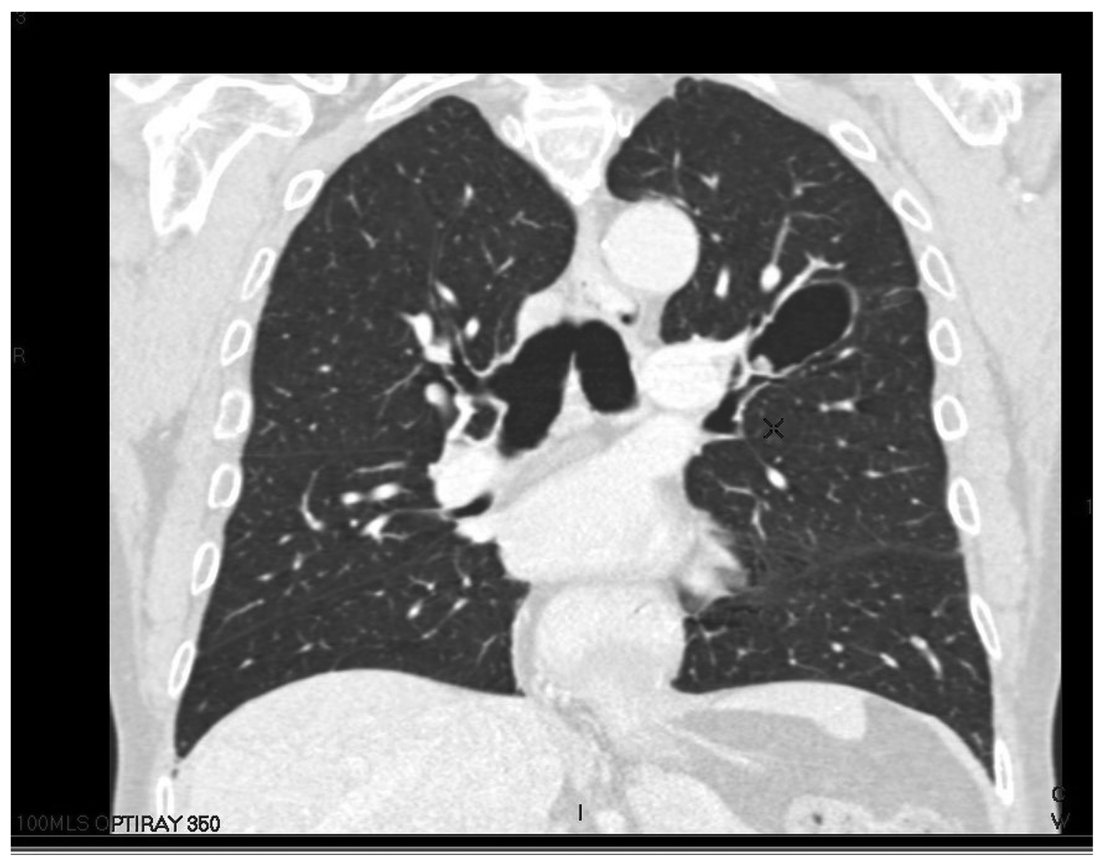

Figure 1 Coronal section of $\mathrm{CT}$ chest showing the $22 \mathrm{~mm}$ cavity in the upper lobe of the left lung with the central small mass consistent with an aspergilloma.

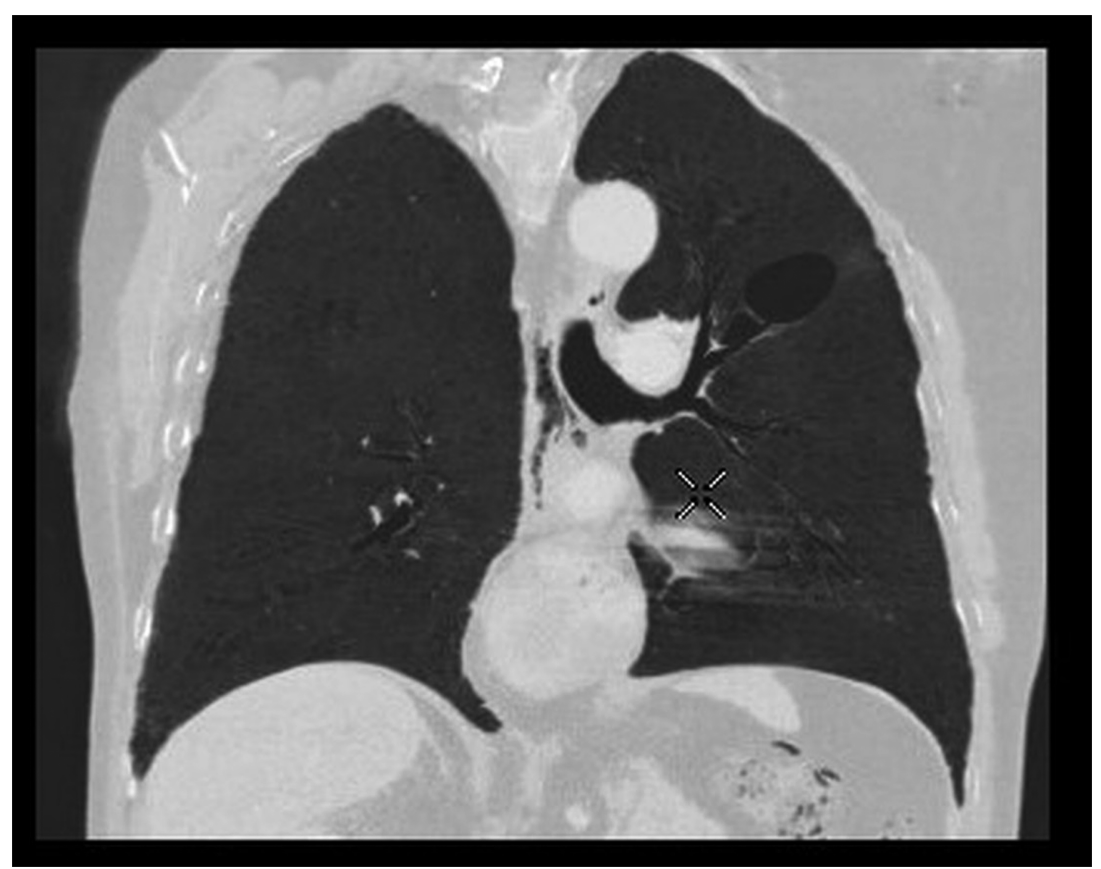

Figure 2 The same CT chest in different view using multi-planar reconstruction (MPR), demonstrating clearly the connection between the aspergilloma-containing cavity and the left main bronchus. 
was found normal. Bronchial brushings showed fungal elements and blood tests confirmed Aspergillus.

He developed a left-sided chest discomfort and increased cough and sputum production whenever he lied on his back or

\section{Learning points}

- Aspergillomas, although usually asymptomatic, can produce more symptoms depending on the site.

- CT scan is useful to decipher the cause of increased symptoms in patients with Aspergilloma. ${ }^{12}$

- This case highlights that immunosuppression is a factor in the development and progression of aspergillus infections. This man had been repetitively treated with corticosteroids, which was the likely source of immunosuppression. ${ }^{13}$ left side, but with no haemoptysis. On review of the CT scan, it was demonstrated that the cavity containing the aspergilloma was connected to the left main bronchus, which would explain these slightly unusual symptoms (figures 1 and 2).

Acknowledgements The author thanks Dr David Sword, her consultant, for providing her with the case and relevant background of the patient.

Competing interests None.

Patient consent Obtained.

Provenance and peer review Not commissioned; externally peer reviewed.

\section{REFERENCES}

1 Brakhage AA. Systemic fungal infections caused by Aspergillus species: epidemiology, infection process and virulence determinants. Curr Drug Targets 2005;6:875-86.

2 Latge JP. Aspergillus fumigatus and Aspergillosis. Clin Microbio Rev 1999;2: 310-50.

3 Palmer LB, Greenberg HE, Schiff MJ. Corticosteroid treatment as a risk factor for invasive aspergillosis in patients with lung disease. Thorax 1991;46:15-20.

Copyright 2014 BMJ Publishing Group. All rights reserved. For permission to reuse any of this content visit

http://group.bmj.com/group/rights-licensing/permissions.

BMJ Case Report Fellows may re-use this article for personal use and teaching without any further permission.

Become a Fellow of BMJ Case Reports today and you can:

- Submit as many cases as you like

- Enjoy fast sympathetic peer review and rapid publication of accepted articles

- Access all the published articles

- Re-use any of the published material for personal use and teaching without further permission

For information on Institutional Fellowships contact consortiasales@bmjgroup.com

Visit casereports.bmj.com for more articles like this and to become a Fellow 